\title{
Pengaruh Ekuitas Merek Terhadap Keputusan Memilih Dengan Minat Sebagai Variabel Intervening
}

\author{
Fathur Rido, Fathor AS, Purnamawati \\ Program Studi Manajemen \\ Fakultas Ekonomi Dan Bisnis \\ Universitas Trunojoyo Madura
}

\begin{abstract}
ABSTRAK
Tujuan dari penelitian ini adalah (1) untuk mengetahui pengaruh signifikan ekuitas merek terhadap minat mahasiswa memilih Universitas Trunojoyo Madura, (2) untuk mengetahui pengaruh signifikan ekuitas merek terhadap keputusan mahasiswa memilih Universitas Trunojoyo Madura, (3) untuk mengetahui pengaruh signifikan minat memilih terhadap keputusan mahasiswa memilih Universitas Trunojoyo Madura, (4) untuk mengetahui pengaruh secara signifikan ekuitas merek terhadap keputusan memilih Universitas Trunojoyo Madura melalui minat memilih sebagai variabel intervening. Metode penelitian ini adalah metode kuantitatif dengan jumlah sampel sebesar 98 responden dengan tehnik sampel yang digunakan adalah Proportinate stratified random sampling,data responden diperoleh dengan menggunakan kuisioner, Analisis yang digunakan adalah analisis jalur (path analysis). Hasil analisis menunjukkan bahwa (1) ekuitas merek berpengaruh signifikan secara langsung terhadap minat memilih, (2) ekuitas merek berpengaruh signifikan secara langsung terhadap keputusan memilih, (3) minat memilih berpengaruh signifikan secara langsung terhadap keputusan memilih, (4) ekuitas merek berpengaruh signifikan secara tidak langsung terhadap keputusan memilih melalui minat memilih. Hasil penelitian menyimpulkan bahwa ekuitas merek telah mampu meciptakan keputusan dan minat memilih Universitas Trunojoyo Madura baik secara langsung maupun tidak langsung.

Kata Kunci : Ekuitas merk, Keputusan memilih, Minat memilih.
\end{abstract}

\section{PENDAHULUAN}

\section{Latar belakang}

Dewasa ini persaingan dunia pendidikan diIndonesia khususnya Jawa Timur sangat ketat.Perguruan tinggi berlomba-lomba meningkatkan kualitas dan melakukan promosi. Berbagai cara dilakukan antara lain, dengan melakukan promosi dengan menggunakan iklan media masa, media cetak, media sosial, penyebaran brosur, presentasi ke SMA-SMA, dan masih banyak lagi. Ada banyak perguruan tinggi baik swasta maupun negeri di Jawa Timur antara lain, Universitas Airlagga (UNAIR), Universitas Brawijaya (UB), Universitas Jember (UNEJ), Politeknik Negeri Banyuwangi(POLIWANGI), Politeknik Negeri Madura (POLTERA), Universitas Madura (UNIRA), IAIN Madura, Universitas Wiraraja Sumenep (UNIJA), Universitas 
Trunojoyo Madura (UTM),

TABEL 1 Data Penerimaan Mahasiswa Baru Universitas Trunojoyo Madura Tahun 2014-2018

\begin{tabular}{|c|c|c|c|c|}
\hline \multirow[b]{2}{*}{ Tahun } & \multicolumn{3}{|c|}{ Diterima } & \multirow[b]{2}{*}{$\begin{array}{l}\text { Juml } \\
\text { ah }\end{array}$} \\
\hline & SNMPN & $\begin{array}{l}\text { SBM } \\
\text { PTN }\end{array}$ & $\begin{array}{l}\text { Mandi } \\
\text { ri }\end{array}$ & \\
\hline 2014 & 1718 & 1812 & 961 & 4.491 \\
\hline 2015 & 1807 & 1554 & 782 & 4.143 \\
\hline 2016 & 1614 & 1515 & 811 & 3.940 \\
\hline 2017 & 1482 & 2172 & 815 & 4.469 \\
\hline 2018 & 1484 & 2680 & 862 & 5.026 \\
\hline
\end{tabular}

Sumber: BAAKPSI. Universitas Trunojoyo Madura (UTM) 2018

Fenomena ini menunjukkan bahwa masih adanya faktor-faktor yang mempengaruhi minat dan keputusan dalam memutuskan memilih Universitas atau perguruan tinggi khususnya (UTM). Faktor faktor tersebut salah satunya berkaitan dengan ekuitas merek Universitas trunojoyo Madura (UTM), seseorang lebih selektif dalam pilihannya untuk memenuhi kebutuhan dan keinginannya. Ekuitas merek tergantung pada upaya membangun merek (brand-building effort) yang dilakukan. Dan nilai ekuitas ini akan berubah-ubah naik atau turun tergantung pada upaya yang dilakukan perguruan tinggi,

Ekuitas merek yang baik akan diingat dan akan menjadi tolak ukur untuk menjadi pertimbangan. Ekuitas Merek (Brand Equity) merupakan nilai tambah yang diberikan pada produk dan jasa yang dapat tercermin dalam cara konsumen berpikir, merasa, dan bertindak dalam hubungannya dengan merek, dan juga harga, pangsa pasar, dan profitabilitas yang diberikan merek bagi perusahaan (Kotler, 2009: 263). Sehingga ketika cara berpikir, merasa dan bertindak mahasiswa mengenai merek meningkat maka dengan sendirinya akan meningkatkan minat beli. Meningkatkan ekuitas merek salah satunya dapat dilakukan memilih nama, logo, identitas merek yang baik. selain itu bisa juga melalui program pemasaran dan komunikasi pemasaran. usaha komunikasi pemasaran yang efektif dan konsisten sangat dibutuhkan untuk membangun dan mempertahankan ekuitas merek. Merek yang memiliki ekuitas tinggi akan merepresentasikan nilai yang baik. Semakin tinggi ekuitas merek, akan semakin tinggi pula value yang akan diberikan merek tersebut. Apabila ekuitas merek meningkat, maka akan meningkat pula tingkat keputusan yang akan diambil.

Keputusan yang dilakukan seseoarang biasanya terjadi setelah adanya minat dari seseorang. keputusan yang melibatkan keyakinan seseorang pada suatu merek sehingga timbul rasa percaya diri atas kebenaran tindakan yang diambil. Rasa percaya diri seseorang atas keputusan yang diambilnya mempresentasikan sejauh mana seseorang memiliki keyakinan diri atas keputusannya memilih suatu merek.(Durianto dkk, 2008: 126) Minat beli timbul ketika seseorang diberikan stimulus yang baik dan berkesan terhadap pemikirannya pada produk atau jasa. Minat membeli sebagai suatu kekuatan pendorong atau sebagai motif yang 
bersifat intrinsic yang mampu mendorong seseorang untuk menaruh perhatian secara spontan, wajar, mudah, tanpa paksaan dan selektif pada suatu produk untuk kemudian mengambil keputusan membeli, Ekuitas Merek bertujuan mengingatkan kembali dan untuk memberikan dorongan pada seseorang agar tertarik dan menumbuhkan minat beli dan mengambil keputusan pembelian. Minat Beli seseorang terjadi karena adanya rasa penasaran dengan hal baru yang menarik perhatiannya sehingga mereka tertarik untuk mencari informasi lebih lanjut dari produk dan merek yang mereka anggap memenuhi kebutuhan dan keinginan mereka sehingga ekuitas merek dapat menjadi menjadi tolak ukur dari minat seseorang yang akan melakukan keputusan pembelian. Terdapat pengaruh differensial positif bahwa jika pelanggan mengenal merek, pelanggan akan merespon produk atau jasa. Terdapat beberapa konsumen yang berfikir sangat rasional sebelum melakukan pembelian, seperti konsumen hanya akan membeli suatu produk apabila memiliki merek yang sudah terkenal dan terbukti di pasar

Minat mahasiswa dan keputusan mahasiswa digambarkan sama dengan minat pembelian dan keputusan pembelian, sehingga teori dan aspek-aspek lainnya pada minat pembelian dan keputusan pembelian akan menggunakan minat memilih dan keputusan memilih. Tujuan yang harapkan bisa dicapai dalam penelitian ini adalah sebagai berikut:

1. Untuk mengetahui pengaruh signifikan ekuitas merek terhadap minat mahasiswa memilih pada Universitas Trunojoyo Madura.

2. Untuk mengetahui pengaruh signifikan ekuitas merek terhadap keputusan mahasiswa memilih pada Universitas Trunojoyo Madura.

3. Untuk mengetahui dan menganalisis pengaruh minat memilih terhadap keputusan memilih mahasiswa pada Universitas Trunojoyo Madura.

4. Untuk mengetahui dan menganalisis pengaruh ekuitas merek terhadap keputusan memilih melalui minat memilih sebagai variabel intervening

\section{TINJAUAN PUSTAKA \\ Pemasaran}

Kotler dan Amstrong (2011: 24) menyatakan Marketing is a societal process by which individuals and groups obtain what they need and want through creating, offering, and freely exchanging products and services of values with others, dengan kata lain pemasaran adalah suatu proses sosial dan manajerial yang didalamnya individu dan kelompok mendapatkan apa yang dibutuhkan dan diinginkan dengan jalan menciptakan, menawarkan, dan menukarkan produk yang bernilai kepada pihak lain, sedangkan menurut Darianto (2004: 4) suatu proses sosial dan manajerial dimana individu dan kelompok mendapatkan kebutuhan dan keinginan mereka dengan menciptakan, menawarkan, dan bertukar sesuatu yang bernilai satu sama lain. Selain itu tim Marknesis (2009: 32) pemasaran adalah fungsi organisasi serta serangkaian proses menciptakan, mengkomunikasikan, menyampaikan nilai bagi para pelanggan serta memberikan manfaat bagi organisasi dan para pemangku kepentingan.

\section{Bauran Pemasaran}

Marketing Mix merupakan kombinasi dari empat variabel atas kegiatan yang merupakan inti dari sistem pemasaran perusahaan yaitu produk, struktur harga, kegiatan promosi, dan sistem distribusi. Ada empat komponen bauran 
pemasaran barang yang meliputi produk, harga, saluran distribusi, promosi dimana penggunaan kombinasi dari keempat variabel tersebut bergantung pada pimpinan perusahaan ataupun seorang manajer, bagaimana mereka dapat menggunakan bauran pemasaran tersebut. (Basu Swastha 2002: 42).

Produk adalah segala sesuatu yang dapat ditawarkan ke suatu pasar untuk memenuhi kebutuhan. Produk-produk yang dipasarkan meliputi barang fisik, jasa, orang, tempat, organisasi dan gagasan (Kotler 2002: 52).

a. Lima tingkatan produk

Dalam merencanakan penawaran atau produk, pemasar perlu memahami lima tingkatan produk yaitu :

1) Produk utama yaitu manfaat yang sebenarnya dibutuhkan atau akan dikonsumsi oleh pelanggan dari setiap produk.

2) Produk generik yaitu produk dasar yang mampu memenuhi fungsi produk yang paling dasar.

3) Produk harapan yaitu produk formal yang ditawarkan dengan berbagai atribut dan kondisinya secara formal diharapkan dandisepakati untuk dibeli.

4) Produk pelengkap yaitu berbagai artibut produk yang dilengkapi atau ditambahi berbagai manfaat dan layanan, sehingga dapat memberikan tambahan kepuasan dan dapat dibedakan dengan produk pesaing.

5) Produk potensial yaitu segala macam tambahan dan perubahanyang mungkin dikembangkan untuk suatu produk dimasamendatang.

b. Atribut Produk

Atribut produk adalah unsur-unsur produk yang dipandang penting oleh konsumen dan dijadikan dasar pengambilan keputusan pembelian, atribut produk meliputi :

1) Merek

2) Kemasan

3) Pemberian label

4) Layanan pelengkap

5) Jaminan

\section{Merek}

Merek sebuah identitas bagi produk agat konsumen mengenal dan mengetahui sebuah produk atau jasa, menurut American Marketing Association (AMA) dalam Kotler (2009: 258) merek merupakan nama, istilah, tanda, lambang atau desain, dan kombinasinya yang dimaksud untuk mengidentifikasi barang atau jasa dari suatu penjual atau kelompok penjual dan dari para pesaing, sedangkan menurut Kartajaya (2010: 62) merek adalah aset yang menciptakan nilai bagi pelanggan dengan meningkatkan kepuasan dan menghargai kualitas. Sementara itu, Koch dalam Wijaja (2005: 31) mendefiniskan merek sebagai sebuah desain visual dan/atau nama yang diberikan kepada suatu produk atau jasa oleh suatu organisasi yang bertujuan untuk membedakan produknya dari produk-produk pesaing dan menjamin konsumen bahwa produk tersebut memiliki kualitas tinggi yang konsisten. Brand adalah identitas tambahan dari suatu produk yang tak hanya membedakannya dari produk pesaing, namun merupakan janji produsen atau kontrak kepercayaan dari produsen kepada konsumen dengan menjamin konsistensi bahwa sebuah produk akan selalu dapat menyampaikan nilai yang diharapkan konsumen dari sebuah produk. 


\section{Ekuitas Merek (Brand Equity)}

Ekuitas merek yang kuat dapat membantu perusahaan untuk menjalin hubungan yang baik dengan para pelanggan dan dapat menghilangkan keraguan pada produk, sangat penting karna gambaran bagi pelanggan untuk mengenal produk, baik atau buruk, layak atau tidak, pantas atau tidak pantas, bisa tertuai dalam cara berfikir konsumen, walaupun pesaing telah melakukan inovasi produk. Perusahaan yang memiliki ekuitas merek yang kuat dapat menentukan harga premium serta mengurangi ketergantungan perusahaan terhadap promosi, Perusahaan yang memiliki ekuitas merek yang kuat dapat menghemat pengeluaran biaya pada saat perusahaan memutuskan untuk melakukan perluasan merek. Ekuitas merek tidak terjadi dengan sendirinya, ekuitas merek dibangun atas elemen elemen (Simamora, $2003: 68$ ) yang terdiri dari:
a. Kesadaran merek
b. Asosiasi merek
c. Persepsi kualitas
d. Loyalitas merek

\section{Minat Beli}

Minat membeli sama dengan keinginan sehingga apa yang diinginkan berarti hal itu yang diminati. Menurut Schiffman dan Kanuk (2007:201) minat membeli merupakan aktivitas psikis yang timbul karena adanya perasaan dan pikiran terhadap suatu barang atau jasa yang diinginkan. Sedangkan Assael (2001: 23) Minat beli sebagai prilaku konsumen yang didasari dengan keinginan dan kebutuhan yang diaplikasikan melalui minat beli sehingga pembelian bisa benar benar dilaksanaka. Terdapat 4 indikator mengenai Minat Beli menurut Ferdinand (2002:129) yaitu:
a. Minat transaksional
b. Minat referensial
c. Minat preferensial
d. Minat eksploratif

\section{Keputusan Pembelian}

Memilih keputusan tidaklah semudah apa yang dibayangkan karna keputusan harus melalui percaya diri yang kuat pada diri yang merupakan keyakinan bahwa keputusan atas pembelian diakatan benar. Menurut Lamb (2008:23), Keputusan membeli yaitu salah satu komponen utama dari perilaku konsumen. Keputusan pembelian yaitu tahap demi tahap yang digunakan konsumen ketika membeli barang dan jasa. Sedangkan menurut Swastha (2007:68) Keputusan pembelian yaitu sebuah pendekatan penyelesaian masalah pada kegiatan manusia untuk membeli suatu barang atau jasa dalam memenuhi keinginan dan kebutuhannya yang terdiri dari pengenalan kebutuhan dan keinginan, pencarian informasi, evaluasi terhadap alternatif pembelian, keputusan pembelian dan tingkah laku setelah pembelian. Menurut Sunyoto, (2013:85), setiap keputusan pembelian mempunyai struktur sebanyak tujuh butir komponen yang terdiri dari :

1) Keputusan tentang jenis produk.

2)Keputusan tentang bentuk produk. 
3) Keputusan tentang merek.

4) Keputusan tentang jumlah produk.

\section{METODE}

\section{Populasi dan Sampel}

Populasi yang digunakan pada penelitian ini adalah seluruh mahasiswa aktif Universitas Trunojoyo Madura tahun 2018 berjumlah 3902 mahasiswa yang tersebar pada prodi di Universitas Trunojoyo Madura.

Sampel yang digunakan Sebanyak 98 mahasiswa tahun 2018 Universitas Trunojoyo Madura, Tehnik sampel yang digunakan dalam penelitian ini adalah Probabilitas Sampel. Probabilitas sampel adalah teknik pengambilan sampel yang memberikan peluang yang sama bagi setiap anggota populasi untuk dipilih menjadi anggota sampel. (Sugiyono, 2012: 82), Sampel yang akan digunakan Sebanyak 98 mahasiswa tahun 2018 Universitas Trunojoyo Madura, Dalam penarikan sempel digunakan tehnik Proportinate stratified random sampling merupakan tehnik yang digunakan bila populasi digunakan atau unsur yang tidak homogen dan berstrata secara proporsional,

\section{HASIL DAN PEBAHASAN}

Uji Hipotesis (analisis jalur)

Analisis jalur atau path analysis digunakan untuk menganalisis pola hubungan antar variabel dengan tujuan untuk mengetahui pengaruh lagsung maupun tidak lagsung seperangkat variabel bebas (endogen) terhadap variabel terikat (eksogen) (Ridwan dan Kuncoro, 2014: 2). Kaidah pengujian dengan persamaan struktural yaitu dengan melihat nilai standardized coefficients $\beta$ dan membandingakan antara probabilitas yang diperoleh dengan probabilitas yang ditentukan, dimana probabilitas yang dipakai adalah $\mathrm{p}<0,05$. Dalam penelitian ini variabel bebas (endogen) adalah ekuitas merek (X), variabel terikat (eksogen) merupakan keputusan memilih (Y), sedangkan minat memilih (Z) merupakan variabel intervening. Operasionalisasi program analisis jalur dilakukan dengan program SPSS 22 for Windows

a. Hasil koefisien jalur ekuitas merek $\mathrm{X}$ terhadap minat memilih $\mathrm{Z}$

Tabel 2

Hasil Koefisien Regresi X ke Z

\begin{tabular}{|l|l|c|}
\hline $\begin{array}{c}\text { Variabel } \\
\text { Bebas }\end{array}$ & $\begin{array}{c}\text { Standard } \\
\text { Coefficient } \\
\boldsymbol{\beta}\end{array}$ & $\begin{array}{c}\text { Prob. Sig } \\
\mathbf{t}\end{array}$ \\
\hline $\begin{array}{c}\text { Ekuitas } \\
\text { merek } \\
(\mathrm{X})\end{array}$ & 0,679 & 0,000 \\
\hline $\begin{array}{l}\text { Variabel } \\
\text { terikat }\end{array}$ & $\begin{array}{l}\text { Minat } \\
\text { memilih }\end{array}$ \\
\hline $\begin{array}{l}\text { R square } \\
\text { Adjused R } \\
\text { Square }\end{array}$ & $: 0,709$ \\
R 0,703 \\
\hline
\end{tabular}


b. Hasil koefisien jalur ekuitas merek $\mathrm{X}$ dan minat memilih $\mathrm{Z}$ terhadap keputusan memilih Y.

Tabel 3

\begin{tabular}{|c|c|c|}
\hline \multicolumn{3}{|c|}{ Hasil Koefisien Regresi X, Z ke } \\
\hline $\begin{array}{l}\text { Variabel } \\
\text { Bebas }\end{array}$ & $\begin{array}{c}\text { Standard } \\
\text { Coefficient } \\
\beta \\
\end{array}$ & $\begin{array}{r}\text { Prob. } \\
\text { Sig t }\end{array}$ \\
\hline $\begin{array}{l}\text { Ekuitas } \\
\text { merek } \\
(\mathrm{X})\end{array}$ & 0,210 & ,007 \\
\hline $\begin{array}{l}\text { Minat } \\
\text { memilih } \\
(Z)\end{array}$ & 0,684 &, 000 \\
\hline $\begin{array}{l}\text { Variabel } \\
\text { terikat }\end{array}$ & $\begin{array}{l}\text { Keputusar } \\
\text { memilih (Y) }\end{array}$ & \\
\hline $\begin{array}{l}\text { R square } \\
\text { Adjused }\end{array}$ & $: 0,708$ & \\
\hline $\begin{array}{l}\mathrm{R} \\
\text { Square }\end{array}$ & $: 0,714$ & \\
\hline $\mathrm{R}$ & $: 0,845$ & \\
\hline
\end{tabular}

\section{Uji Koefisien Determinasi $\left(\mathbf{R}^{\mathbf{2}}\right)$}

Berdasarkan hasi analisis jalur model 1 dapat diketahui bahwa nilai Adjusted Square atau $\mathrm{R}^{2}$ sebesar 0,703 atau $70,3 \%$ menunjukkan besarnya pengaruh ekuitas merek dapat dijelaskan oleh minat memilih sedangkan sisanya sebesar 0,297 atau 29,7\% dijelaskan oleh variabel lain yang tidak diteliti dalam penelitian ini.

Sedangkan model 2 Nilai Adjusted Square atau $\mathrm{R}^{2}$ sebesar 0,714 atau 71,4\% menunjukkan besarnya pengaruh ekuitas merek dapat dijelaskan oleh minat memilih sedangkan sisanya sebesar 0,286 atau $28,6 \%$ dijelaskan oleh variabel lain yang tidak diteliti dalam penelitian ini

\section{Uji simultan (Uji F)}

Koefisien jalur secara keseluruhan digunakan uji $\mathrm{F}$ untuk mengetahui apakah terdapat pengaruh secara simultan antara variabel independen terhadap variabel dependen.

Hal ini dapat dijelaskan dari Fhitung yang menunjukkan nilai sebesar 115,787 lebih besar dari Ftabel sebesar 3,09 dengan signifikansi sebesar 0,000 < dari 0,05 . Dalam hal ini $\mathrm{dfl}=\mathrm{k}-1$ dan $\mathrm{df} 2=\mathrm{N}-\mathrm{k}$, dimana $\mathrm{N}$ merupakan jumlah sampel yang diteliti dan $\mathrm{k}$ adalah jumlah variabel yang terlibat dalam penelitian. Dengan demikian minat memmilih merupakan variabel intervening antara ekuitas merek dan keputusan memilih. Selain dapat memberikan pengaruh langsung maupun tidak langsung melalui minat memilih, dalam penelitian ini juga membuktikan bahwa ekuitas merekl dan minat memilih mampu memberikan pengaruh secara simultan terhadap keputusan memilih. 


\section{Uji Parsial (Uji t)}

1. koefisien jalur $X$ ke $Z$ sebesar 0,679 dengan hasil $t$ hitung sebesar 9,072 $>\mathrm{t}$ tabel 1,98525 dan nilai signifikansi sebesar $0,000<0,05$. Ekuitas merek secara langsung berpengaruh signifikan terhadap minat memilih.

2. koefisien jalur $\mathrm{X}$ ke $\mathrm{Y}$ sebesar 0,210 dengan dengan hasil $\mathrm{t}$ hitung sebesar $2,759>\mathrm{t}$ tabel 1,98525 dan nilai signifikansi sebesar $0,000<0,05$. Ekuitas merek secara langsung berpengaruh signifikan terhadap keputusan memilih.

3. koefisien jalur $\mathrm{Z}$ ke $\mathrm{Y}$ sebesar 0,684 dengan hasil t hitung sebesar 8,991 $>\mathrm{t}$ tabel 1,98525 dan nilai signifikansi sebesar $0,000<0,05$. minat memilih secara langsung berpengaruh signifikan terhadap keputusan memilih

4. hasil analisis jalur menunjukkan adanya hubungan signifikan antara ( $\mathrm{X}$ ke $\mathrm{Z}) \mathrm{x}$ ( $\mathrm{Z}$ ke Y) atau $0,000 \times 0,00=0,000$. diterima ekuitas merek $(\mathrm{X})$ berpengaruh signifikan secara tidak langsung terhadap keputusan memilih (Y) melalui minat memilih $(Z)$ dengan pengaruh 0,464 atau $46,4 \%$.

\section{Hubugan Antar Jalur}

Hasil anlisis jalur secara keseluruhan dalam penelitian ini menunjukkan bahwa pengaruh masing masing jalur yang dilewati ketiga variabel adalah signifikan

1. Ekuitas merek secara langsung berpengaruh signifikan terhadap minat memilih Universitas Trunojoyo Madura dengan koefisien jalur sebesar 0,679

2. Ekuitas merek secara langsung berpengaruh signifikan terhadap keputusan memilih universitas trunojoyo madura sehingga dengan koefisien jalur sebesar 0,210

3. Minat memilih secara langsung berpengaruh signifikan terhadap keputusan memilih Universitas Trunojoyo Madura dengan koefisien jalur 0,684

4. Ekuitas merek berpengaruh signifikan secara tidak langsung terhadap keputusan memilih melalui minat memilih universitas trunojoyo madura dengan koefisien jalur sebesar 0,464

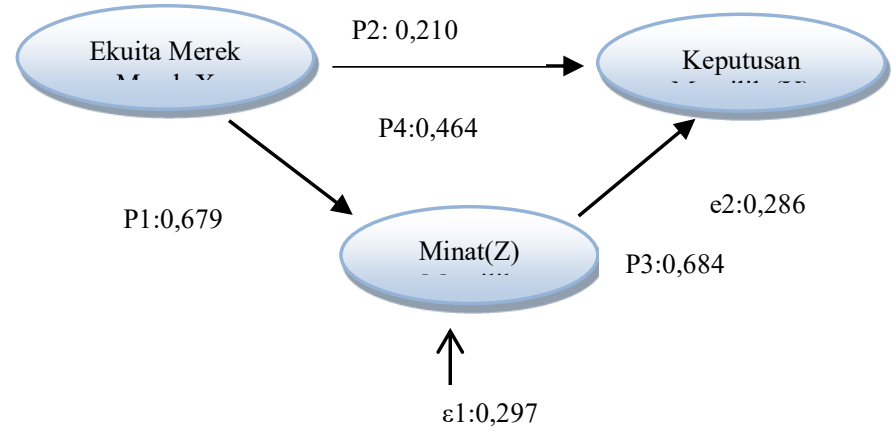

Gambar 2 Hasil Diagram Jalur

Persamaan struktural dari hasil analisis ini sebagai berikut:

$\mathrm{Z}: 0,679 \mathrm{X}+0,297 \mathrm{e} 1$

$\mathrm{Y}: 0,210 \mathrm{X}+0,684 \mathrm{Z}+0,286 \mathrm{e} 2$ 


\section{PEMBAHASAN}

Ekuitas merek yang baik akan diingat dan akan menjadi tolak ukur untuk menjadi pertimbangan, Meningkatkan ekuitas merek dapat dilakukan dengan memilih nama, logo, identitas merek yang baik. selain itu bisa juga melalui program pemasaran dan komunikasi pemasaran. usaha komunikasi pemasaran yang efektif dan konsisten sangat dibutuhkan untuk membangun dan mempertahankan ekuitas merek. Merek yang memiliki ekuitas tinggi akan merepresentasikan nilai yang baik. Semakin tinggi ekuitas merek, akan semakin tinggi pula value yang akan diberikan merek tersebut, Ekuitas Merek bertujuan mengingatkan kembali dan untuk memberikan dorongan pada seseorang agar tertarik dan menumbuhkan minat beli dan mengambil keputusan pembelian. Minat Beli seseorang terjadi karena adanya rasa penasaran dengan hal baru yang menarik perhatiannya sehingga mereka tertarik untuk mencari informasi lebih lanjut dari produk dan merek yang mereka anggap memenuhi kebutuhan dan keinginan mereka.

\section{Pengaruh Secara Langsung Ekuitas merek (X) Minat memilih (Z).}

Hasil analisis ini memberikan informasi bahwa ekuitas merek Universitas Trunojoyo Madura melalui indikator kesadaran merek, asosiasi merek, persepsi kualitas, loyalitas merek dan item item pernyataan telah mampu menciptakan minat kepada mahasiswa, dan jika indikator ekuitas merek ditingkatkan tentu akan semakin meningkat minat memilih universitas trunojoyo madura. Universitas Trunojoyo Madura menyadari hal itu dengan membangun infrastruktur dan berbagai prasarana untuk penunjang ekuitas merek,

Universitas Trunojoyo Madura sudah memiliki berbagai fasilitas yang cukup memadai, sarana dan berbagai sara tidak kalah dengan universitas yang ada di Madura bahkan yang ada di Jawa Timur, meski Madura dikenal dengan cuaca dan tanahnya yang gersang dengan ekuitas merek Universitas Trunojoyo Madura menjadi pertimbangan mereka untuk memilih atau menjadi pendidikan tingkat lanjut yang mereka pilih Hasil analisis ini mendukung hasil penelitian yang dilakukan Agusli dkk, (2013:1-8) dan Irzandy dkk (2017:156) yang menyatakan bahwa ekuitas merek memiliki pengaruh terhadap minat beli.

\section{Pengaruh Secara Langsung Ekuitas merek (X) Terhadap Keputusan Memilih} (Y)

Hasil analisis ini memberikan informasi bahwa ekuitas merek Universitas Trunojoyo Madura melalui indikator kesadaran merek, asosiasi merek, persepsi kualitas, loyalitas merek dan item item pernyataan, ekuitas merek telah mampu mencitakan keputusan kepada mahasiswa untuk memilih universitas trunojoyo madura, dan jika indikator ekuitas merek ditingkatkan tentu akan semakin meningkatkan keputusan untuk memilih universitas trunojoyo madura. Meningkatan ekuitas merek merupakan hal yang tepat,

Mahasiswa yang memutuskan untuk memilih Universitas Trunojoyo Madura sebagai pendidikan tingkat lanjut tentu saja telah memikirkan begitu matang dan sudah melewati beberapa pertimbangan, salah satunya karena merupakan perguruan tinggi negeri, fasilitas cukup memadai, dan terlebih dahulu mengetahui keunggulannya, selain itu juga dengan berbagai macam prodi dan konsentrasi yang ditawarkan.Hasil dari penilitian ini mendukung hasil penelitian 
yang dilakukan oleh Pradipta dkk (2016:34) dan Muhammad Aries dkk, (2018: 67). yang menyatakan bahwa minat beli berpengaruh terhadap keputusan pembelian.

\section{Pengaruh Secara Langsung Minat memilih (Z) Terhadap Keputusan memilih} (Y)

Hasil analisis ini memberikan informasi bahwa minat memilih Universitas Trunojoyo Madura melalui indikator minat transaksional, minat refrensial, minat preferensial, minat eksploratif dan item item pernyataan minat memilih telah mampu mencitakan keputusan kepada mahasiswa untuk memilih universitas trunojoyo madura, dan jika indikator minat memilih ditingkatkan tentu akan semakin meningkatkan keputusan untuk memilih Universitas Trunojoyo Madura. mahasiswa akan berfikir dan merasa universitas trunojoyo madura telah dilihat dari aspek aspek fasilitas dan lain sebagainya akannn bisa menimbulkan keputusan untuk memilih universitas trunojoyo madura.

Mahasiswa memilih Universitas Trunojoyo Madura tanpa paksaan dengan kata lain memang menginginkan dengan mencari informasi tentang keungulan keunggulannya tidak sampai disitu juga bahkan mahasiwa telah merekomendasikan kepada siswa siswi/adik adik tingkatnya di SLTA dan mengatakan hal hal yang menarik minat sehingga dapat mempengaruhi agar supaya memutuskan memilih Universitas Trunojoyo Madura sbagai pendidikan tingkat lanjut. Hasil penilitian ini mendukung penilitian yang dilakukan oleh Muhammad Aries dkk, (2018: 67). yang menyatakan bahwa minat beli berpengaruh terhadap keputusan pembelian.

\section{Pengaruh Tidak Langsung Ekuitas merek (X) Terhadap Keputusan memilih (Y) Melalui minat memilih (Z)}

Hasil analisis ini memberikan informasi bahwa ekuitas merek Universitas Trunojoyo Madura melalui indikator kesadaran merek, asosiasi merek, persepsi kualitas, loyalitas merek dan item item pernyataan ekuitas merek telah mampu menciptakan minat kepada mahasiswa dan mendorong agar mereka memutuskan untuk memilih, dan jika indikator ekuitas merek ditingkatkan tentu akan semakin meningkat minat memilih terhadap keputusan memilih Universitas Trunojoyo Madura.

Minat memilih sebagai instrumen mediasi untuk memutuskan memilih Universitas Trunojoyo Madura, Sarana yang telah diperbaiki dan dikembangkan merupakan tolak ukur mengaktifkan minat dan bahkan keputusan, ketika merek ini sudah tertanam dengan baik maka dengan sendirinya usaha promosi akan menjadi lebih efektif. Hasil dan analisi ini mendukung penelitian yang dilakukan oleh Irzandy dkk, (2017: 156) yang mengatakan bahwa ekuitas merek berpengaruh terhadap keputusan melalui minat pembelian

\section{KESIMPULAN}

Hasil analisis dari penelitian ini menunjukkan bahwa:

1. Ekuitas Merek (X) berpengaruh signifikan secara langsung terhadap minat memilih (Z) pada Universitas Trunojoyo Madura

2. Ekuitas Merek (X) berpengaruh signifikan secara langsung terhadap keputusan memilih (Y) pada Universitas Trunojoyo Madura 
3. Minat memilih $(Z)$ berpengaruh signifikan secara langsung terhadap keputusan memilih (Y) pada Universitas Trunojoyo Madura

4. Ekuitas Merek (X) berpengaruh signifikan secara tidak langsung terhadap keputusan memilih (Y) melalui minat memilih (Z) pada Universitas Trunojoyo Madura

\section{SARAN}

Berdasarkan temuan yang diperoleh dari temuan ini, maka isampaikan beberapa saran yang diharapkan berguna untuk kepentingan praktis dan penelitian selanjutnya sebagai berikut:

1. Bagi civitas akademik universitas trunojoyo madura

Ekuitas merek memiliki pengaruh yang sangat besar untuk meningkatkan minat dan keputusan memilih universitas trunojoyo madura dengan demikian diharapkan mampu meningkatkan ekuitas merek dengan saran prasara dilengkapi dan dikembangkan secara lebih lagi, membangun komunikasi atau melakukan promosi yang lebih dengan siswa slta sederajat serta mengembangkan mahasiswa sehingga dapat berprestasi untuk seterusnya meningkatkan nilai yang akan diberikan.

2. Bagi Peneliti Selanjutnya

Peneliti belum memasukkan variabel lain yang relevan sehingga disarankan kepada peneliti selanjutnya untuk memasukkan lebih banyak variabel lain. Selain itu metode mengumpulkan data dengan kuisioner dihadapkan dengan beberapa persoalan, diantaranya memunculkan erasaan senang dan tidak senang responden, keseriusan dan faktor situsional lain ketika responden memberikan jawaban yang berakibat munculnya subjektifitas, sehingga untuk peneliti selanjutnya untuk menyiapkan waktu lebih panjang dalam menyebarkan kuisioner dan lebih memperhatiakan situsai dan kondisi responden.

\section{DAFTAR PUSTAKA}

Agusli, Devonalita dan Yohanes Sondang K. 2013. Analisa Pengaruh Dimensi Ekuitas Merek Terhadap Minat Beli Konsumen Midtown Hotel Surabaya. Jurnal. Manajemen Pemasaran Petra. Vol.1 No.2 1-8.

Akhtar. Naeem, dkk 2016. Impact of a Brand Equity on Consumer Purchase Decision in L'Oreal Skincare Products. Journal. International Review of Management and Bussiness Research. Vol. 5 Issue 3.

BAAKPSI, 2018. Data Penerimaan Mahasiswa Baru Universitas Trunojoyo Madura

Bilson Simamora, 2003. Memenangkan Pasar dengan Pemasran Efektif Dan Profitable Jakarta : Gramedia Pustaka Utama

Charles Lamb, W .et.al 2008. Pemasaran, Edisi kelima. Jakarta: Selemba Empat

Durianto, Damardi, Sugiarto, Setinjak, Toni. 2004. Strategi Menaklukan Pasar Melalui Riset Ekuitas dan Perilaku Mere. Jakarta : Gramedia Pustaka Utama

Durianto, Darmadi, Sugiarto, Sitinjak, Toni. 2008. Strategi Menaklukkan Pasar Melalui Perilaku Merek. Jakarta. Gramedia Pustaka Utama.

Engel, James F \& Roger D. Blackwell. 2008. Perilaku Konsumen. Diterjemahkan oleh Budiyanto. Edisi 6 Jilid 2. Tangerang: Binarupa Aksara. 
Ferdinand, A, 2002. Metode Penelitian Manajemen, Pedoman Penelitian untuk Skripsi, Tesis, dan Devertasi Ilmu Manajemen, Semarang: Universitas Diponegoro

Ferinadewi, Erna, 2008. Merek dan Psikologi Konsumen, Yogyakarta: Graha Ilmu

Irzandy Haris, dkk 2017. Pengaruh Ekuitas Merek Terhadap Minat Beli Dan Dampaknya Pada Keputusan Pembelian (Survei Pada Pengguna Kartu Perdana Simpati Khusus Internet Di Grapari Telkomsel Cabang Kota Malang). Jurnal Administrasi Bisnis (JAB) Vol. 51 No.1.

Kartajaya, Hermawan. 2010. Konsep Pemasaran. Jakarta : PT Gramedia

Kemendikbud. 2012. Undang undang RI No 12 tahun 2012 tentang pendidikan tinggi.http:sipuu.setkab.go.id/PUUdoc/17624/UU0122012.Full.pdf. diakses 19 november 2018.

Kotler, Philip dan Armstrong, Gary. 2008. Prinsip-prinsip pemasaran. Alih Bahasa Bob Sabran. Jakarta: Penerbit Erlangga.

Kotler, Philip dan Kevin L. Keller 2009. Manajemen Pemasaran. Edisi 13. Alih Bahasa Bob Sabran. Jakarta : Penerbit Erlangga.

Marknesis, Tim. 2009 Pemasaran: Strategi, Takti Dan Kasus. Edisi Pertama Jakarta : Penerbit Jelajah

Pradipta, dkk 2016. Pengaruh Brand Equity Terhadap Keputusan Pembelian. Jurnal Administrasi Bisnis (JAB)|Vol. 34 No. 1 Mei

Rangkuti, Freddy. 2009. The Power Of Brands Tehnik Mengelola Brand Equity dan Strategi Pengembangan Merek. Jakarta: Penerbit PT. Gramedia Pustaka Utama.

Ratna Cynthia, dkk. 2014. Purchase Intention In Automotive Industry A Case Study Of Abc In Surabaya. Journal. International Review of Management and Bussiness Research. Vol. 7 Issue 8.

Riduwan \& Kuncoro. 2014. Cara Menggunakan Dan Memaknai Path Analysis Atau Analisis Jalur Lengkap Dengan Contoh Tesis Dan Perhitungan SPSS 17.0. Bandung: Alfabeta

Rukmi Dyah Kusumawardani Ambar dkk, 2018. Analisa Pengaruh Dimensi Ekuitas Merek Terhadap Minat Beli Konsumen Midtown Hotel Surabaya.

Schifman, Leo dan Leslie L, Kanuk. 2007. Prilaku Konsumen. Edisi 7. Jakarta: PT. Indeks

Soenyoto Felly Liliyana, 2015. The Impact Of Brand Equity On Brand Preference And Purchase Intention In Indonesia's Bicycle Industry. Journal. International Review of Management. Vol. 2 Issue 34.

Sugiyono, 2015. Metode Penelitian Kuantitatif Kualitatif dan R\&D. Bandung: Alfabeta

Tjiptono, Fandy, 2008. Pemasaran Strategik, Edisi 1. Yokyakarta: CV Andy Offset 